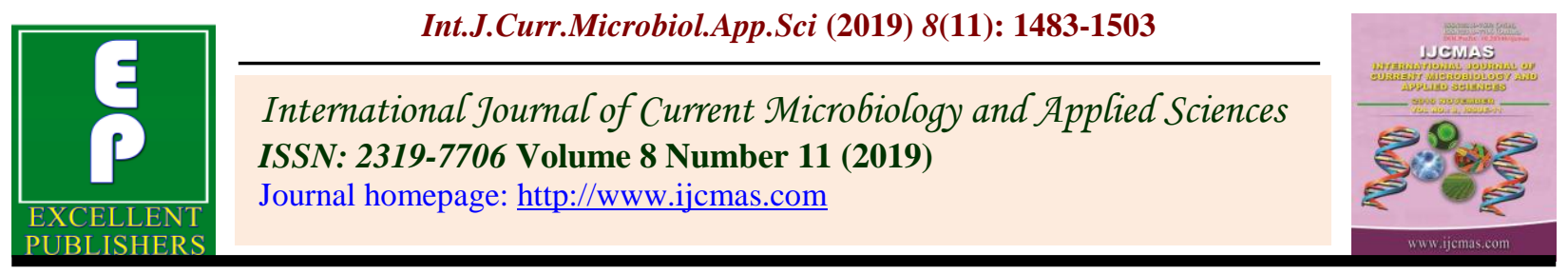

\title{
Production Evaluation of Wheat through the Use of Different Cultivation Practices Using Different Machineries at Agricultural Machinery Testing and Research Centre (AMTRC), Sarlahi, Nepal
}

\author{
Ram Nath Jha*, Md. Shamshad Ansari, Manish Thakur and Ram Abtar Mahato
}

Agricultural Machinery Testing and Research Centre (AMTRC), Nawalpur, Sarlahi, Nepal

*Corresponding author

\begin{tabular}{|l|}
\hline K e y w o r d s \\
Mechanization, \\
Wheat, Herbicide, \\
PTOSD (minimum \\
tillage), Rotavator, \\
Gross margin
\end{tabular}

\section{A B S T R A C T}

In Nepal an agricultural plays vital role in Nepalese economy. Rice, Maize, Buckwheat, Wheat are major cereal crop of Nepal. Among this wheat is a third major cereal crop of Nepal and first winter crop. Due to youth and Skilled Manpower migration in urban areas and in gulf countries in search of better opportunities, Agriculture in Nepal is facing labor scarcity. Lack of human resources in agriculture has compelled farmers to find out alternate choice and mechanization in wheat farming is one of the best solutions for better production, less drudgery, quick operations and better farm income. In order to address this issue, an experiment on uses of different agricultural machineries and cultivation practices in wheat crop was conducted at AMTRC, Sarlahi during 2074/075 and 2075/076. Experiments were carried out in three replications with five treatments in $2800 \mathrm{~m}^{2}$ plot size. The variety of wheat was Gautam and was sown at the rate of 120kg/ha. Fertilizers were applied @ 100:60:60 kg NPK/ha. Herbicide applied was 2-4-D and Pendymethaylen @ 5ml/litre of water. Irrigation and other cultural practices were followed as per recommendation. The pooled analysis of two years data of grain yield was significant at one per cent level. The highest yield of $3547.50 \mathrm{~kg} / \mathrm{ha}$ was obtained in treatment $\mathrm{T}_{3}$ (minimum tillage) where power tiller operated seed drill (PTOSD) machine was used for wheat cultivation followed by the treatment $\mathrm{T}_{4}(3456.67 \mathrm{~kg} / \mathrm{ha})$ where rotavator zero tiller was used. The lowest mean grain yield $(3005.00 \mathrm{~kg} / \mathrm{ha})$ was recorded in $\mathrm{T}_{2}$ for which seed sowing rotavator was used in experiment. The average gross margin of two years was obtained highest (Rs. 63840.07/ha) by $\mathrm{T}_{3}$ where the power tiller operated seed drill machine was used for wheat cultivation. The total variable cost in use of PTOSD machine in $\mathrm{T}_{3}$, was 17.58 per cent less than farmers' practices. Similarly the gross margin was also 25.92 per cent more than farmer's practices (Check) obtained in PTOSD machine used treatment. The production was also highest in this treatment among other practices which was $3547.50 \mathrm{~kg} / \mathrm{ha}$, and this yield was more than 10 per cent higher than farmer's practices. 


\section{Introduction}

Nepal is a small, land-locked mountainous country with diverse agro ecologies. It is an agricultural country having 66 per cent people directly engaged in farming (FAO, 2019). Agriculture contributes almost one third of the national economy (NPC, 2017). Agricultural crop productivity in Nepal is lowest among South Asian countries (FAO, 2018). Farming is still subsistence in nature and different agricultural crops are integrated with livestock. Rice, maize, wheat, millet, barley and buckwheat are the major staple foods grown in the country. During the year 2074/075 the contribution of agriculture, forestry and fishery to gross domestic product was 27.59 per cent which has been expected as 26.98 during the fiscal year of 2075/076 (MoF, 2019). The agricultural sector production during 2074/075 was increased by 2.7 per cent which has been estimated as 5.1 per cent in 2075/076 (MoF, 2019).

Wheat is the third most important crop after rice and maize both in area and production. It is a winter season main crop. Farmers now a day have diversified agricultural system and gradually shifting towards fishery, vegetable and cash crop cultivation resulting 2.9 per cent reduction in area of wheat during 2075/076 covering 686557 ha. in the country. Despite this decline in area, due to increase in uses of improved seeds as seed replacement rate increased to 15.1 per cent from 14.00 per cent, the increment in production and productivity has been estimated to be increased by 4.5 and 7.6 per cent, respectively to harvest 2036706 mt. of wheat grains (MoF, 2019). Wheat contributed 23.62 per cent to total edible cereal grain production of Nepal in the year 2016/2017 (ASS, 2018).

According to CIMMYT, wheat contributes about 21 per cent to the cereal area and 19 per cent to the cereal production. Nepal can be divided into two distinct wheat production zones:

One belt, containing the terai, tars, and lower valleys up to 600 meter above sea level (masl), experiences a subtropical climate and has the most fertile soil. This is, by far, the best and the largest wheat production zone comprising the plains area of the terai running east-west in the extreme south as well as other areas of similar environment, i.e., inner terai, foothills, lower valleys, and river basins. The rice wheat rotation is the predominant system of this zone.

The second belt, containing the mid-and high hills and running east-west between the terai and the Himalayas, experiences a warm to cool temperate climate. The rice-wheat rotation is common in the mid-hills $(600-1700$ masl) while maize-wheat is common in the high hills (above 1700 masl).

Wheat during the year of 2007/2008 in Nepal was cultivated in 70648.00 ha which produced $1572065.00 \mathrm{mt}$ with an average yield of $225.00 \mathrm{~kg} / \mathrm{ha}$ (Table 1). Area under wheat during 2016/2017 increased to 735850.00 ha and similarly, production and productivity reached to $1879191.00 \mathrm{mt}$ and $2554.00 \mathrm{~kg} / \mathrm{ha}$ respectively (ASS, 2018).

Although the area and production of wheat in the country is in increasing trend, but is in slow rate (Figure 1).

Wheat contributes about $20 \%$ of the total cereal production in Nepal. Over 60\% of wheat is produced in the Terai (plain) region, though they are also produced in the mid hills and high hills regions of Nepal (Timsina et al., 2018). Many farmers are shifting from wheat cultivation in winter to other off season vegetables, fisheries and cash crops. However, the productivity is in increasing trend (Figure 2) due to increase in application of manure 
and fertilizer, quality seeds, and increased in application of improved cultivation practices, increased farmers' awareness in technology adoption, improved skill and knowledge in wheat cultivation There is fluctuation in yield increment caused by sometimes input unavailability and sometimes by weather. In future, the focus seems to be given to increase productivity through the application of most advanced inputs and cultural practices with mechanization in wheat cultivation, because the chances of increasing area are least.

The wheat production and productivity has also been influenced by climatic factors which have now a day known as impact due to climate change. Devkota and Phuyal (2015) found significant positive impact of the average and maximum temperature and significant negative impact of the minimum temperature on net revenue and wheat yield of terai region. Similarly, they also found the mixed impacts of precipitation on wheat production. With the maximum temperature, increase in temperature reduces net revenue and wheat yield whereas with average and minimum temperature, precipitation increases wheat yields as well as revenue.

By 2020, demand for wheat is expected to be $40 \%$ greater than its current level of 552 million tons (Rosegrant et al., 1997), but the resources available for wheat production are likely to be significantly lower. Between 1961 and 1994, wheat yields increased at an average annual rate of more than 2 per cent in all developing countries except China and India (Pingali and Heisey, 1996). Food insecurity in Nepal is a major problem with more than two third of the districts facing food deficit every year (Joshi et al., 2012).

Farm mechanization has been imperative in present labor scarce situation for agricultural works in Nepal. Farm mechanization includes use of machines, whether mobile or immobile, small or large, run by power and used for tillage operations, harvesting and threshing. It also includes power lifts for irrigation, trucks for haulage of farm produce, processing machines and many others. Mechanization of farm indicates the use of machines for conducting agricultural operations replacing the traditional methods which involve human and animal labor. In other words, mechanization is a process of replacing biological sources of energy involving animal and human labor to mechanized source of energy which includes various machines like tractors, threshers, harvesters, pump sets, cultivator, seed sowing rotavator, zero till seed drill, rotavator zero tiller, combined harvester etc. In other words mechanized agriculture is the process of using agricultural machinery to mechanize the work of agriculture, greatly increasing farm worker productivity. In modern times powered machinery has replaced many farm jobs formerly carried out by manual labor or by working animals. Thus mechanization can be defined as the art of using machineries to hasten production, accomplish task and reduce fatigue and human labor in order to produce better quality goods and services.

Agriculture in Nepal is perceived as most drudgeries occupation due to lack of appropriate farm mechanization and the prevalence of subsistence farming. Therefore, farm mechanization is critically important to attenuate these problems and enhance the farm productivity, profitability, efficiency, and hence the food security in the country.

In Nepal-terai, agricultural mechanization related tools used are manual tools, animal drawn implements and mechanical power operated machinery. More than 51 per cent of holding in terai own and use animal drawn iron plough due to increased field efficiency than traditional plough and easy availability in border towns (Shrestha, 2012). The major 
sources of farm power in Nepal are animal power $(36.3 \%)$, human power $(40.5 \%)$ and the mechanical power (23\%). In another study conducted at Bhaktapur in 2003-2004, Shrestha $_{b}$ (2012) concluded that single pass of power tiller operated roto-tiller saves cost for land preparation by 40 per cent than tillage by 2 passes of power tiller with roto-tiller (local practice) with about 5 per cent increased average yield of wheat. Similarly, based on on-farm study conducted at Bhaktapur in year 2005-2006, it was concluded that minimum till drill (Chinese seed drill) saves cost for land preparation by 61 per cent than tillage by 2 passes of power tiller with roto-tiller (local practice) with about 22 per cent increased average yield of wheat. Study conducted in Belwa VDC indicates that the zero till drill saves about 65 per cent of the cost of tillage and seeding than the traditional practice and with 4 per cent increase in yield of wheat.

In Nepal labor shortage has also created a sense of following mechanization in agriculture. In the recent years, agriculture sector in Nepal is facing acute labor shortage due to rapidly increasing labor outmigration, especially migration towards the golf countries in search of better employment opportunities The labor shortage in agriculture sector has increased the rural labor wage rates (Wang et al., 2016; Wiggins and Keats, 2014). Adoption and spread of agricultural and rural mechanization technologies are increasing recently in Nepal with liberal import policies, increased connectivity and acute labor scarcity resulting from youth migration. Feminization in agriculture is apparent. In addition, spillover effect from India also played important role in the promotion of mechanization in the bordering terai districts. Agriculture machinery is having appositive impact on small holders since they are efficient in accomplishing timely farm operations, reducing cost and improving product quality (Gauchan and Shrestha, 2017).
Farmers in hills are also found interested in mechanization as everywhere there is a lack of manpower due to youth migration. In an assessment of smallholder farmers' willingness to pay for scale appropriate farm mechanization by taking the case of mini tiller technology in the mid-hills Nepal carried out by Paudel et al., (2019) showed that farm size, on-farm wage rates, number of household members migrated, access to credit services, and association with cooperatives were the farm level attributes that are positively associated with willingness to pay for minitillers. This study also revealed that farmers' average willingness to pay was 31 per cent lower than actual technology price.

Network models, particularly Graphical Evaluation and Review Technique (GERT) networks are increasingly powerful tool for modeling, scheduling, planning, controlling, and analyzing of agricultural mechanization projects (Abdi et al., 2010). In a study conducted by Din and Khattak (2018) in Peshawar valley, Pakistan, found the per acre productivity of mechanized farmers a little bit greater than the non-mechanized farmers.

A complete mechanization happens only if all farming operations are done by machines reducing human labor and displacing animal labor completely. But in a country like Nepal, where there is scarce of capital can apply partial mechanization. When there is acute shortage of labor, then we have to think for complete mechanization, although there are many problems for complete mechanization in Nepal. Even the partial mechanization has also not been introduced in potential areas of the country. Mechanization increases the rapidity and speed of work with which farming operations can be performed. It raises the efficiency of labor and enhances the farm production per farm worker and thus reduces the quantum of labor needed to produce a unit of output in the farm. 
Farm mechanization has been a most important factor to increase production and productivity of agricultural crops in Nepal. Evidence suggests that mechanization has a major impact on demand and supply of farm labor, agricultural profitability, and a change in rural landscape and can be defined as an economic application of engineering technology to increase the labor efficiency and productivity. The United Nation Food and Agriculture Organization (FAO) and the United Nations Industrial Development Organization (UNIDO) concluded that the goal of agricultural mechanization is to reduce labor (Emami et al., 2018). Mechanization reduces labor requirement. Aurangzeb et al., (2007) in a study in Peshawar district of Pakistan found that labor requirements of the mechanized farms were nearly $20 \%$ of that of the traditional farms. A unit application of agricultural machinery reduces labor requirements by over 3 times. The input prices and labor have inverse relation. The output and animal power encourage labor requirements.

Although there is increase in the uses of farm machinery, still it requires more for the augmentation of agricultural products. It has significant role in the commercialization of agriculture in Nepal under present context of labor scarcity. Marahatta et al., (2018) found higher yield of both rice and wheat (4106; $3042 \mathrm{~kg} / \mathrm{ha}$ ) in conservation agriculture than as compared to conventional agriculture (4106; 3022 kg/ha). The mechanization reduces cost of cultivation and increases yield than that of traditional farms. Rahaman et al., (2011) reported that the less number of labors per hectare is required to complete the production process by mechanized farm compared to traditional farms. The yield of wheat under mechanization $(2.65 \mathrm{mt} / \mathrm{ha})$ was higher than that of traditional farms (2.57 $\mathrm{mt} / \mathrm{ha}$ ) in Bangladesh. The study carried out by Yamin et al., (2011) revealed a good scope of increment in production of wheat by increasing and managing agricultural machines in Punjab-Pakistan. Hossain and Collaghan (2011) found oxen to be the most expensive solution and power tillers the cheapest in wheat cultivation in Bangladesh. Cultural and economic constraints have hindered the widespread adoption of more expensive precision agriculture technologies like zero-till that have the capacity to improve labor and farm input efficiencies in wheat cultivation in Nepal (Mcdonald et al., 2018).

In Nepal, farm mechanization formally started from 1970s with the advent two and four wheel tractors (Takeshima, 2017 ). While Basnyat (2017) reported that the beginning of modern age started after Mr. Krishna Bahadur Thapa of Biratnagar first time imported single cylinder tractor. Takesima (2017 a) reported that less than 8 per cent farms used farm mechanization in the hills, while 46 per cent farms used mechanization in the terai area indicating the low level of farm mechanization in Nepalese hills. Since the 1990s, the Government of Nepal has been implementing national agricultural policies to reduce poverty and induce sustainable economic growth through commercialization and competitiveness in agriculture. Some of the policies adopted by the government are: Agriculture Perspective Plan (APP), Agribusiness Promotion Policy (AgPP), Agriculture development Strategy (ADS), and Agriculture Mechanization Promotion Policy (AMPP). While APP, AgPP and ADS are concerned with the overall agriculture development, the AMPP specifically focuses on the promotion of mechanization of agriculture in Nepal (Sharma, 2017).

Agriculture mechanization is one of the key processes that will affect the future of small holder farming systems in Asian countries, including Nepal, where just 8 per cent of farmers use tractors, 26 per cent use iron 
plows, and more than 60 per cent of intercultural operations are managed by women (Kaur, 2017). Study carried out by GC et al., (2019) showed that light machinery is an essential part of Nepali farming system. Likewise, the presence of animal power, income per capita, per capita farm area, adaptation due to change in temperature, household size, farm area and income are significant determinants for total investment in farm mechanization. Pradhan et al., (2016) found much higher family income in tractor owned farms than bullock farms due to the higher income from off-farm activities in Sunsari district. Using geographical information system, they also observed that about 96.8 per cent of the total cultivated area can be covered using tractor, and 1.5 per cent can at least be served with power tillers. In the remaining 1.7 per cent area neither tractor nor power tiller can operate efficiently.

Since mechanization in wheat cultivation is gradually taking place particularly in terai region, farmers need to be well acquainted with the uses of different machineries in their farm and their impact on production, productivity and overall farm income.

In order to convey the actual performance of different cultivation practices in wheat farming, study is needed to evaluate the performance of different machineries for different cultivation practices. Agricultural Machinery Testing and Research Centre (AMTRC) Office, Nawalpur, Sarlahi is carrying out different research activities by using different machineries to find out efficient methods of mechanization in wheat cultivation. A study was also carried out to evaluate the cultivation practices through different machineries under on-station condition. Different machineries were used to evaluate their performance and impact on wheat yield at Sarlahi during 2074/2075 and 2075/2076.

\section{Materials and Methods}

Different machines used for wheat cultivation were identified at AMTRC, Nawalpur, Sarlahi. The cultivation practices for wheat cultivation by using different machineries were evaluated in five treatments (Table 2).

The trials were carried out in three replications of five treatments in $2800 \mathrm{~m}^{2}$ plot size for each treatment. The experiment was laid out in randomized complete block design (RCBD). The variety of wheat was Gautam. Seeds were sown in second-third week of Marga (Last week of November to first week of December) at the rate of $120 \mathrm{~kg} / \mathrm{ha}$. The crop was harvested in the last week of Chaitra (First week of April). The row to row distance was maintained as $18-20 \mathrm{~cm}$ in power tiller operated seed drill and rotavator zero till operated treatment. The herbicides used for controlling weeds were 2-4-D and Pendymethaylen sprayed at the rate of $5 \mathrm{ml} /$ litre of water. No any insecticides were sprayed as incidences of pests were not observed in the crop.

The fertilizer doses supplied were at the rate of 100:60:60 kg NPK kg/ha. The full dose of phosphorous, potash and half dose of nitrogen were applied as basal dose during the time of land preparation while remaining half dose of nitrogen was top dressed after 30 and 60 days of sowing, respectively. The source of phosphorous was Di-ammonium phosphate (DAP) and that of potassium was muirate of potash and of nitrogen was DAP and urea.

First irrigation was given after 20-22 days of sowing and the second irrigation after 80 days. Other intercultural practices were followed as per need and recommendation for this crop. Data were recorded on date of sowing, date of harvesting, plant height, spike length, number of plant per square meter area and average number of grain per spike of wheat. Similarly, 
average number of tiller per hill, thousand grains weight, grain yield and straw yield per hectare were also recorded.

The data were fed into computer and analyzed using ms-excel and Mstat package. The data recorded were analyzed for individual parameters separately for each year. Similarly, the combined analysis was performed for two years data.

\section{Results and Discussion}

\section{Plant height}

Plant height during 2074/075 was found significant at 1 per cent level, while it was non-significant during 2075/076. In pooled analysis of two years data, the effect of year was non-significant and interaction between year and treatment was significant at 5 per cent level. But the treatments in combined analysis were significant at 1 per cent level (Table 3). During 2074/075, the maximum plant height was attained in $\mathrm{T}_{2}(92.2 \mathrm{~cm})$ followed by $\mathrm{T}_{3}$ which recorded $92.11 \mathrm{~cm}$ plant height in the experiment. In combined analysis of two years data, the highest plant height was recorded in $T_{3}(91.72 \mathrm{~cm})$ followed by $T_{5}$ $(91.28 \mathrm{~cm})$. The lowest plant height of 82.94 $\mathrm{cm}$ was recorded in $\mathrm{T}_{4}$ (Table 3 ).

\section{Spike length}

The spike length was significant at 1 per cent level in 2074/2075 while it was nonsignificant in 2075/076 (Table 4). In pooled analysis, the effect of year was found significant at 1 per cent level.

During the year 2074/075 the maximum spike length of $10.89 \mathrm{~cm}$ was recorded in $\mathrm{T}_{3}$ while that was lowest in $\mathrm{T}_{4}$ which was $8.11 \mathrm{~cm}$. Similarly, during the second year 2075/076 of the experiment, the highest spike length of $12.77 \mathrm{~cm}$ was observed in $\mathrm{T}_{1}$ and the lowest in
$\mathrm{T}_{2}$ which was $11.00 \mathrm{~cm}$ only. In combined analysis, the spike length was highest in $\mathrm{T}_{1}$ $\left(11.61 . \mathrm{cm}\right.$ ) and lowest of $9.94 \mathrm{~cm}$ in $\mathrm{T}_{4}$ (Table 4).

\section{Plant population}

The plant population per square meter was non-significant in both of the years and thus in combined analysis too (Table 5). However, in pooled analysis the average number of plant per square meter was observed highest in $\mathrm{T}_{2}$ which was 80.67 followed by 79.42 in $T_{4}$.

\section{Grain per spike}

The number of grain per spike, when analyzed statistically was found non-significant in both of the years (2074/075 and 2075/076). Ultimately it was also non-significant in combined analysis (Table 6). The average of two years result showed the highest number of grain per spike in $\mathrm{T}_{3}(54.16)$ and lowest in $\mathrm{T}_{4}$ (49.22).

\section{Tiller number}

The number of tiller per hill in the wheat trial was non-significant in 2074/075 and $2075 / 076$. Similarly it was also non-significant in combined analysis (Table 7). In combined analysis, the effect of year was found significant at 5 per cent level. In average of two years data, the maximum number of tiller/hill was obtained in $_{3}$ followed by $T_{1}$ which was 6.16 and 6.09 , respectively. The $\mathrm{T}_{4}$ recorded lowest number of 5.55 tiller per hill in the experiment (Table 7).

\section{Thousand grain weight}

The weight of 1000 grains of wheat in experiment was significantly different at 1 per cent level in 2074/075 and at 5 per cent level in 2075/076. The interaction between year and treatments was also significant at one per cent 
level (Table 8) in combined analysis. The weight of 1000 grain was highest in $\mathrm{T}_{4}$ (49.69 gram) and lowest in $\mathrm{T}_{5}$ (48.47 gram) in 2074/075. Similarly, in 2075/076, 47.14 gram of 100 grains was observed in $\mathrm{T}_{5}$ followed by $\mathrm{T}_{1}$ which recorded 47.03 gram. The average of two years 1000 grain weight was obtained highest in $\mathrm{T}_{4}$ which recorded 48.25 gram followed by $\mathrm{T}_{1}$ (47.82 gram) and the lowest weight of 47.69 gram was observed in $\mathrm{T}=$ (Table 8).

\section{Grain yield}

The mean grain yield of wheat in 2074/075 was significant at 1 per cent level and it was non-significant in 2075/076. Similarly, the yield difference in combined analysis was also significant at 1 per cent level and the interaction of year and treatment was also significant at 1 per cent level in the experiment (Table 9). During the same year the highest mean grain yield of $3661.67 \mathrm{~kg} / \mathrm{ha}$ was recorded in $T_{3}$ followed by $T_{4}$ which obtained $3480 \mathrm{~kg} / \mathrm{ha}$. The lowest mean grain yield was observed in $\mathrm{T}_{2}$ which was 2626.67 $\mathrm{kg} / \mathrm{ha}$ in 2074/075. Despite non-significant result of treatments in 2075/076, $\mathrm{T}_{5}$ recorded highest mean grain yield of $3516.67 \mathrm{~kg} / \mathrm{ha}$ and the lowest yield of $3018.33 \mathrm{~kg} / \mathrm{ha}$ was found in $T_{1}$. In combined analysis of two years yield data, $\mathrm{T}_{3}$ recorded the highest mean grain yield of $3547.50 \mathrm{~kg} / \mathrm{ha}$ and the lowest was 3005.00 $\mathrm{kg} / \mathrm{ha}$ obtained in $\mathrm{T}_{2}$ (Table 9).

\section{Straw yield}

The mean straw yield was found significant at 5 per cent level in 2074/075 while it was nonsignificant in 2075/076. In combined analysis the effect of year was found significant at 1 per cent level while that of interaction between year and yield was non-significant (Table 10). The highest mean straw yield of $3960.00 \mathrm{~kg} / \mathrm{ha}$ was obtained in T4 during 2074/075 followed by T3 which recorded
$3930.00 \mathrm{~kg} / \mathrm{ha}$ in the experiment. Similarly, the lowest straw yield was obtained in T2 which was observed as $3323.33 \mathrm{~kg} / \mathrm{ha}$. In 2075/076, $\mathrm{T}_{5}$ produced highest mean straw yield of $4903.33 \mathrm{~kg} / \mathrm{ha}$. The average straw yield of two years was found highest in T3 which obtained $4351.67 \mathrm{~kg} / \mathrm{ha}$ (Table 10).

\section{Gross Margin}

A gross margin is the difference between the gross income and the variable costs of producing a crop. It is a guide to the earning potential of a particular crop in an average situation after the growing costs have been met. Gross margins do not measure farm profits as they do not take into consideration fixed or overhead expenses. A gross margin refers to the total income derived from an enterprise less the variable costs incurred in the enterprise. A gross margin for an enterprise is its financial output minus its variable costs. One of the major benefits of mechanization is reduction of cost of production and ultimately the increment in farm income.

In this experiment gross margins of each treatment were calculated for individual year of 2074/075 (Table 11) and 2075/076 (Table 12). The average of two years (Table 13) was also calculated which has been taken as concluding remarks for briefing the benefit of mechanization in this experiment. The detail of variable costs and revenue for 2074/075 (Annex-1), 2075/076 (Annex-2) and average of two years (Annex-3) are also calculated to show expenses and revenue of different activities and products, respectively. The total variable costs incurred during 2074/075 was highest in check $\mathrm{T}_{5}$ which was Rs. 49469.80/ha and the lowest was Rs. 42069.80/ha in $\mathrm{T}_{3}$. The total revenue from grain and straw products was obtained highest in $\mathrm{T}_{3}$ (Rs. 101366.50ha) followed by $\mathrm{T}_{4}$ (Rs. 96900.00/ha). 
Table.1 Area, production and yield of wheat (2007/2008-2016/2017) in Nepal

\begin{tabular}{|c|c|c|c|}
\hline Year & Area (Ha) & $\begin{array}{c}\text { Production } \\
\text { (Mt) }\end{array}$ & Yield (Kg/ha) \\
\hline $\mathbf{2 0 0 7 / 2 0 0 8}$ & 706481.00 & 1572065.00 & 2225.00 \\
\hline $\mathbf{2 0 0 8 / 2 0 0 9}$ & 694950.00 & 1343862.00 & 1934.00 \\
\hline $\mathbf{2 0 0 9 / 2 0 1 0}$ & 731131.00 & 1556539.00 & 2129.00 \\
\hline $\mathbf{2 0 1 0 / 2 0 1 1}$ & 767499.00 & 1745811.00 & 2275.00 \\
\hline $\mathbf{2 0 1 1 / 2 0 1 2}$ & 765317.00 & 1846142.00 & 2412.00 \\
\hline $\mathbf{2 0 1 2 / 2 0 1 3}$ & 759843.00 & 1882220.00 & 2477.00 \\
\hline $\mathbf{2 0 1 3 / 2 0 1 4}$ & 754474.00 & 1883147.00 & 2496.00 \\
\hline $\mathbf{2 0 1 4 / 2 0 1 5}$ & 762373.00 & 1975625.00 & 2591.00 \\
\hline $\mathbf{2 0 1 5} / \mathbf{2 0 1 6}$ & 745823.00 & 1736849.00 & 2329.00 \\
\hline $\mathbf{2 0 1 6 / 2 0 1 7}$ & 735850.00 & 1879191.00 & 2554.00 \\
\hline
\end{tabular}

Source: GoN/MoALC/MESD/Agriculture Statistics Section, Singhdurbar, Kathmandu, 2018.

Table.2 Treatments followed in wheat experiment at Sarlahi

\begin{tabular}{|c|c|c|c|}
\hline $\begin{array}{c}\text { Treatment } \\
\text { no. }\end{array}$ & $\begin{array}{c}\text { Treatments } \\
\mathbf{T}_{\mathbf{1}}\end{array}$ & $\begin{array}{c}\text { Cultivator } \\
\text { seed sowing } \\
\text { and rotavator } \\
\text { (CSR) }\end{array}$ & $\begin{array}{c}\text { In this treatment while preparing the land, first primary } \\
\text { tillage was done with the use of cultivator. After the } \\
\text { land preparation, seeds of Gautam variety of wheat } \\
\text { were broadcasted followed by fertilizer broadcasting. } \\
\text { After broadcasting of seeds and fertilizer the field was } \\
\text { tilled with rotavator. }\end{array}$ \\
\hline $\mathbf{T}_{\mathbf{2}}$ & $\begin{array}{c}\text { Seed sowing } \\
\text { and rotavator } \\
\text { (SR) }\end{array}$ & $\begin{array}{c}\text { In this treatment, seeds and fertilizers were } \\
\text { broadcasted in the field followed by tilling with } \\
\text { rotavator }\end{array}$ \\
\hline $\mathbf{T}_{\mathbf{3}}$ & $\begin{array}{c}\text { Power tiller } \\
\text { operated seed } \\
\text { drill } \\
\text { (PTOSD) }\end{array}$ & $\begin{array}{c}\text { In this treatment, four operations were performed in } \\
\text { one pass. First operation was tilling the field, the } \\
\text { second was seed sowing, the third operation was } \\
\text { fertilizer application and the forth one was planking } \\
\text { the field for level maintenance. }\end{array}$ \\
\hline $\mathbf{T}_{\mathbf{4}}$ & $\begin{array}{c}\text { Rotavator and } \\
\text { zero till seed } \\
\text { drill (RZ) }\end{array}$ & $\begin{array}{c}\text { The field was first tilled with rotavator and then seeds } \\
\text { and fertilizers were applied with zero tiller seed drill } \\
\text { machine. }\end{array}$ \\
\hline $\mathbf{T}_{\mathbf{5}}$ & $\begin{array}{c}\text { Check } \\
\text { (Farmer's } \\
\text { practices }\end{array}$ & $\begin{array}{c}\text { In this treatment, the prevailing farmers' practices } \\
\text { were followed. The field was given first preparation by } \\
\text { ploughing with cultivators. After preparing the land } \\
\text { with cultivators, the seeds were broadcasted followed } \\
\text { by the broadcasting of fertilizers. The land was again } \\
\text { tilled by using cultivators and then planked finally. }\end{array}$ \\
\hline
\end{tabular}


Table.3 Average plant height of wheat at AMTRC, Sarlahi (2074/075-2075/076)

\begin{tabular}{|c|c|c|c|c|}
\hline \multirow{2}{*}{$\begin{array}{c}\text { Tr. } \\
\text { no. }\end{array}$} & Treatments & \multicolumn{3}{|c|}{ Plant height (Cm) } \\
\hline & & $2074 / 2075$ & $2075 / 2076$ & Combined \\
\hline $\mathbf{T}_{\mathbf{1}}$ & Cultivator seed sowing and rotavator & $86.11^{\mathrm{b}}$ & 91.88 & $89.00^{\mathrm{a}}$ \\
\hline $\mathbf{T}_{\mathbf{2}}$ & Seed sowing and rotavator & $92.22^{\mathrm{a}}$ & 89.44 & $90.83^{\mathrm{a}}$ \\
\hline $\mathbf{T}_{\mathbf{3}}$ & Power tiller operated seed drill & $92.11^{\mathrm{a}}$ & 91.33 & $91.72^{\mathrm{a}}$ \\
\hline $\mathbf{T}_{\mathbf{4}}$ & Rotavator and zero tiller seed drill & $80.55^{\mathrm{c}}$ & 85.33 & $82.94^{\mathrm{b}}$ \\
\hline $\mathbf{T}_{\mathbf{5}}$ & Check (Farmers' practices) & $94.11^{\mathrm{a}}$ & 88.44 & $91.28^{\mathrm{a}}$ \\
\hline & F test & $* *$ & Ns & - \\
\hline & CV (\%) & 1.88 & 4.49 & - \\
\hline & LSD (1\%) & 4.6 & - & - \\
\hline & Pooled: & & & \\
\hline & Grand mean & & & 89.15 \\
\hline & F test: & & & \\
\hline & Year (Y) & & & $*$ \\
\hline & Treatment (T) & & $*$ \\
\hline & Y x T & & & 3.45 \\
\hline & CV (\%) & & 5.18 \\
\hline & LSD for T (1\%) & & 5.32 \\
\hline
\end{tabular}

Note: $* *=$ Significant at 1 per cent level, $*=$ Significant at $5 \%$ level, Ns=Non-significant. Any two means having a common letter are not significantly different at the given level of significance.

Table.4 Average length of spike of wheat at AMTRC, Sarlahi (2074/075-2075/076)

\begin{tabular}{|c|c|c|c|c|}
\hline \multirow{2}{*}{$\begin{array}{c}\text { Tr. } \\
\text { no. }\end{array}$} & Treatments & \multicolumn{3}{|c|}{ Spike length $(\mathbf{C m})$} \\
\hline & & $2074 / 2075$ & $2075 / 2076$ & Combined \\
\hline $\mathbf{T}_{\mathbf{1}}$ & Cultivator seed sowing and rotavator & $10.44^{\mathrm{a}}$ & 12.77 & 11.61 \\
\hline $\mathbf{T}_{\mathbf{2}}$ & Seed sowing and rotavator & $10.88^{\mathrm{a}}$ & 11.00 & 10.94 \\
\hline $\mathbf{T}_{\mathbf{3}}$ & Power tiller operated seed drill & $10.89^{\mathrm{a}}$ & 12.11 & 11.50 \\
\hline $\mathbf{T}_{\mathbf{4}}$ & Rotavator and zero tiller seed drill & $8.11^{\mathrm{b}}$ & 11.77 & 9.94 \\
\hline $\mathbf{T}_{\mathbf{5}}$ & Check (Farmers' practices) & $10.22^{\mathrm{a}}$ & 12.00 & 11.11 \\
\hline & F test & $*^{\mathrm{a}}$ & $\mathrm{Ns}$ & - \\
\hline & CV (\%) & 7.76 & 10.61 & - \\
\hline & LSD (1\%) & 0.96 & - & - \\
\hline & Pooled: & & & \\
\hline & Grand mean & & & 11.02 \\
\hline & F test: & & & $* *$ \\
\hline & Year (Y) & & & Ns \\
\hline & Treatment (T) & & & Ns \\
\hline & Y x T & & 9.56 \\
\hline
\end{tabular}

Note: ** = Significant at 1 per cent level, *= Significant at $5 \%$ level, Ns=Non-significant. Any two means having a common letter are not significantly different at the given level of significance. 
Table.5 Average number of plant/m² of wheat at AMTRC, Sarlahi (2074/075-2075/076)

\begin{tabular}{|c|c|c|c|c|}
\hline Tr. & Treatments & \multicolumn{3}{|c|}{ Number of plant/ square meter } \\
\cline { 3 - 5 } no. & & $2074 / 207$ & $2075 / 207$ & Combined \\
\hline & & 5 & 6 & \\
\hline $\mathbf{T}_{\mathbf{1}}$ & Cultivator seed sowing and rotavator & 68.17 & 79.17 & 73.67 \\
\hline $\mathbf{T}_{\mathbf{2}}$ & Seed sowing and rotavator & 80.00 & 81.33 & 80.67 \\
\hline $\mathbf{T}_{\mathbf{3}}$ & Power tiller operated seed drill & 76.17 & 78.50 & 77.33 \\
\hline $\mathbf{T}_{\mathbf{4}}$ & Rotavator and zero tiller seed drill & 77.17 & 81.67 & 79.42 \\
\hline $\mathbf{T}_{\mathbf{5}}$ & Check (Farmers' practices) & 74.50 & 78.50 & 76.50 \\
\hline & F test & Ns & Ns & - \\
\hline & CV (\%) & 7.16 & 7.72 & - \\
\hline & Pooled: & & & \\
\hline & Grand mean & & & 77.52 \\
\hline & F test: & & & Ns \\
\hline & Year (Y) & & Ns \\
\hline & Treatment (T) & & Ns \\
\hline & Y x T & & 7.47 \\
\hline
\end{tabular}

Note: $* *=$ Significant at 1 per cent level, $*=$ Significant at $5 \%$ level, Ns=Non-significant.

Table.6 Average number of grain per spike of wheat at AMTRC, Sarlahi (2074/075-2075/076)

\begin{tabular}{|c|c|c|c|c|}
\hline \multirow{2}{*}{$\begin{array}{c}\text { Tr. } \\
\text { no. }\end{array}$} & Treatments & \multicolumn{3}{|c|}{ Number of grain/spike } \\
\cline { 3 - 5 } & & $2074 / 2075$ & $2075 / 207$ & Combined \\
& & & 6 & \\
\hline $\mathbf{T}_{\mathbf{1}}$ & Cultivator seed sowing and rotavator & 50.66 & 52.11 & 51.38 \\
\hline $\mathbf{T}_{\mathbf{2}}$ & Seed sowing and rotavator & 53.44 & 45.11 & 49.27 \\
\hline $\mathbf{T}_{\mathbf{3}}$ & Power tiller operated seed drill & 55.44 & 52.89 & 54.16 \\
\hline $\mathbf{T}_{\mathbf{4}}$ & Rotavator and zero tiller seed drill & 49.00 & 49.44 & 49.22 \\
\hline $\mathbf{T}_{\mathbf{5}}$ & Check (Farmers practices) & 5.55 & 57.66 & 56.61 \\
\hline & F test & Ns & Ns & - \\
\hline & CV (\%) & 8.48 & 11.93 & - \\
\hline & LSD (1\%) & - & - & - \\
\hline & Pooled: & & & \\
\hline & Grand mean & & & \\
\hline & F test: & & & Ns \\
\hline & Year (Y) & & Ns \\
\hline & Treatment (T) & & Ns \\
\hline & Y x T & & 10.30 \\
\hline
\end{tabular}

Note: $* *=$ Significant at 1 per cent level, $*=$ Significant at $5 \%$ level, Ns=Non-significant. 
Table.7 Average number of tiller per hill of wheat at AMTRC, Sarlahi (2074/075-2075/076)

\begin{tabular}{|c|c|c|c|c|}
\hline \multirow{2}{*}{$\begin{array}{l}\text { Tr. } \\
\text { no. }\end{array}$} & Treatments & \multicolumn{3}{|c|}{ Number of tiller/hill } \\
\cline { 3 - 5 } & & $2074 / 207$ & $2075 / 207$ & Combined \\
\hline $\mathbf{T}_{\mathbf{1}}$ & Cultivator seed sowing and rotavator & 5 & 6 & \\
\hline $\mathbf{T}_{\mathbf{2}}$ & Seed sowing and rotavator & 7.40 & 4.77 & 6.09 \\
\hline $\mathbf{T}_{\mathbf{3}}$ & Power tiller operated seed drill & 7.33 & 4.33 & 5.75 \\
\hline $\mathbf{T}_{\mathbf{4}}$ & Rotavator and zero tiller seed drill & 6.55 & 4.55 & 6.16 \\
\hline $\mathbf{T}_{\mathbf{5}}$ & Check (Farmers' practices) & 6.33 & 5.33 & 5.85 \\
\hline & F test & Ns & Ns & - \\
\hline & CV (\%) & 15.62 & 44.95 & - \\
\hline & Pooled: & & & \\
\hline & Grand mean & & & 5.87 \\
\hline & F test: & & & $*$ \\
\hline & Year (Y) & & & Ns \\
\hline & Treatment (T) & & & Ns \\
\hline & Y x T & & 29.05 \\
\hline
\end{tabular}

Note: $* *=$ Significant at 1 per cent level, $*=$ Significant at $5 \%$ level, Ns=Non-significant.

Table.8 Average weight of 1000 grains of wheat at AMTRC, Sarlahi (2074/075-2075/076)

\begin{tabular}{|c|c|c|c|c|}
\hline \multirow{2}{*}{$\begin{array}{c}\text { Tr. } \\
\text { no. }\end{array}$} & Treatments & \multicolumn{3}{|c|}{ 1000 grain weight $(\mathbf{G m})$} \\
\hline & & $2074 / 2075$ & $2075 / 2076$ & Combined \\
\hline $\mathbf{T}_{\mathbf{1}}$ & Cultivator seed sowing and rotavator & $48.60^{\mathrm{b}}$ & $47.03^{\mathrm{a}}$ & 47.82 \\
\hline $\mathbf{T}_{\mathbf{2}}$ & Seed sowing and rotavator & $49.43^{\mathrm{a}}$ & $45.95^{\mathrm{c}}$ & 47.69 \\
\hline $\mathbf{T}_{\mathbf{3}}$ & Power tiller operated seed drill & $49.17^{\mathrm{ab}}$ & $46.45^{\mathrm{b}}$ & 47.81 \\
\hline $\mathbf{T}_{\mathbf{4}}$ & Rotavator and zero tiller seed drill & $49.69^{\mathrm{a}}$ & $46.82^{\mathrm{ab}}$ & 48.25 \\
\hline $\mathbf{T}_{\mathbf{5}}$ & Check (Farmers' practices) & $48.47^{\mathrm{b}}$ & $47.14^{\mathrm{a}}$ & 47.80 \\
\hline & F test & $* *$ & $*$ & - \\
\hline & CV (\%) & 0.76 & 0.72 & - \\
\hline & LSD (1\%) & 0.72 & 0.41 & - \\
\hline & LSD (5\%) & & 0.44 & - \\
\hline & Pooled: & & & \\
\hline & Grand mean & & & 47.88 \\
\hline & F test: & & & $*$ \\
\hline & Year (Y) & & Ns \\
\hline & Treatment (T) & & $* *$ \\
\hline & Y x T & & & 0.74 \\
\hline & CV (\%) & & 0.84 \\
\hline
\end{tabular}

Note: $* *=$ Significant at 1 per cent level, $*=$ Significant at $5 \%$ level, Ns=Non-significant. Any two means having a common letter are not significantly different at the given level of significance. 
Table.9 Mean grain yield of wheat at AMTRC, Sarlahi (2074/075-2075/076)

\begin{tabular}{|c|c|c|c|c|}
\hline \multirow{2}{*}{$\begin{array}{l}\text { Tr. } \\
\text { no. }\end{array}$} & \multirow[t]{2}{*}{ Treatments } & \multicolumn{3}{|c|}{ Mean grain yield $(\mathrm{Kg} / \mathrm{ha})$} \\
\hline & & $2074 / 2075$ & $2075 / 2076$ & Combined \\
\hline $\mathbf{T}_{1}$ & Cultivator seed sowing and rotavator & $3070.00^{\mathrm{b}}$ & 3018.33 & $3044.17^{b}$ \\
\hline $\mathbf{T}_{2}$ & Seed sowing and rotavator & $2626.67^{\mathrm{c}}$ & 3383.33 & $3005.00^{\mathrm{b}}$ \\
\hline $\mathbf{T}_{3}$ & Power tiller operated seed drill & $3661.67^{\mathrm{a}}$ & 3433.33 & $3547.50^{\mathrm{a}}$ \\
\hline $\mathbf{T}_{4}$ & Rotavator and zero tiller seed drill & $3480.00^{\mathrm{a}}$ & 3433.33 & $3456.67^{\mathrm{a}}$ \\
\hline $\mathbf{T}_{5}$ & Check (Farmers' practices) & $3123.33^{b}$ & 3516.67 & $3320.00^{\mathrm{ab}}$ \\
\hline & F test & ** & Ns & 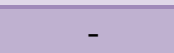 \\
\hline & $\mathrm{CV}(\%)$ & 3.03 & 9.06 & - \\
\hline & $\operatorname{LSD}(1 \%)$ & 118.7 & - & - \\
\hline & Pooled: & & & \\
\hline & Grand mean & & & 3274.67 \\
\hline & F test: & & & \\
\hline & $\overline{\operatorname{Year}(\mathrm{Y})}$ & & & Ns \\
\hline & Treatment $(\mathrm{T})$ & & & ** \\
\hline & $\mathrm{YxT}$ & & & ** \\
\hline & $\mathrm{CV}(\%)$ & & & 6.90 \\
\hline & LSD for $\mathrm{T}(1 \%)$ & & & 380.80 \\
\hline & LSD for $\mathrm{Y} \times \mathrm{T}(1 \%)$ & & & 538.50 \\
\hline
\end{tabular}

Note: $* *=$ Significant at 1 per cent level, $*=$ Significant at $5 \%$ level, Ns=Non-significant. Any two means having a common letter are not significantly different at the given level of significance.

Table.10 Mean straw yield of wheat at AMTRC, Sarlahi (2074/075-2075/076)

\begin{tabular}{|c|c|c|c|c|}
\hline \multirow{2}{*}{$\begin{array}{l}\text { Tr. } \\
\text { no. }\end{array}$} & Treatments & \multicolumn{3}{|c|}{ Mean straw yield (Kg/ha) } \\
\hline & & $2074 / 2075$ & $2075 / 2076$ & Combined \\
\hline $\mathbf{T}_{\mathbf{1}}$ & Cultivator seed sowing and rotavator & $3686.67^{\mathrm{b}}$ & 4536.67 & 4111.67 \\
\hline $\mathbf{T}_{\mathbf{2}}$ & Seed sowing and rotavator & $3323.33^{\mathrm{c}}$ & 4666.67 & 3995.00 \\
\hline $\mathbf{T}_{\mathbf{3}}$ & Power tiller operated seed drill & $3930.00^{\mathrm{a}}$ & 4773.33 & 4351.67 \\
\hline $\mathbf{T}_{\mathbf{4}}$ & Rotavator and zero tiller seed drill & $3960.00^{\mathrm{a}}$ & 4565.33 & 4262.67 \\
\hline $\mathbf{T}_{\mathbf{5}}$ & Check (Farmers' practices) & $3630.00^{\mathrm{b}}$ & 4903.33 & 4266.67 \\
\hline & F test & 6.37 & 13.53 & - \\
\hline & CV (\%) & 198.7 & - & - \\
\hline & LSD (5\%) & & & \\
\hline & Pooled: & & & 4197.53 \\
\hline & Grand & & \\
\hline & F teant: & & & $* *$ \\
\hline & Year (Y) & & & Ns \\
\hline & Treatment (T) & & Ns \\
\hline & Y x T & & 11.40 \\
\hline & CV (\%) & & 380.80 \\
\hline & LSD for T (1\%) & & 538.50 \\
\hline
\end{tabular}

Note: $* *=$ Significant at 1 per cent level, $*=$ Significant at $5 \%$ level, Ns=Non-significant. Any two means having a common letter are not significantly different at the given level of significance. 
Table.11 Gross margin of wheat (Rs./ha) at AMTRC, Sarlahi during 2074/2075

\begin{tabular}{|c|c|c|c|c|c|c|}
\hline $\begin{array}{c}\text { S. } \\
\text { No. }\end{array}$ & Particulars & $\begin{array}{c}\mathbf{T}_{\mathbf{1}} \\
(\mathbf{C S R})\end{array}$ & $\begin{array}{c}\mathbf{T}_{\mathbf{2}} \\
\mathbf{( S R )}\end{array}$ & $\begin{array}{c}\mathbf{T}_{\mathbf{3}} \\
\text { (PTOSD) }\end{array}$ & $\begin{array}{c}\mathbf{T}_{\mathbf{4}} \\
\text { (RZ) }\end{array}$ & $\begin{array}{c}\mathbf{T}_{\mathbf{5}} \\
\text { (Check) }\end{array}$ \\
\hline & Variable costs: & & & & & \\
\hline 01. & Land preparation cost & 6500.00 & 7000.00 & 4000.00 & 6750.001 & 10500.00 \\
\hline $\mathbf{0 2 .}$ & Seed cost & 9000.00 & 9000.00 & 9000.00 & 9000.00 & 9000.00 \\
\hline $\mathbf{0 3 .}$ & Fertilizer cost & 11819.80 & 11819.80 & 11819.80 & 11819.80 & 11819.80 \\
\hline $\mathbf{0 4 .}$ & Herbicide cost & 1350.00 & 1350.00 & 1350.00 & 1350.00 & 1350.00 \\
\hline $\mathbf{0 5 .}$ & Labor cost & 6300.00 & 6300.00 & 5400.00 & 5400.00 & 6300.00 \\
\hline 06. & Machine hire cost & 10500.00 & 10500.00 & 10500.00 & 10500.00 & 10500.00 \\
\hline & Total variable costs & 45469.80 & 45969.80 & 42069.80 & 44819.80 & 49469.80 \\
\hline & Revenue: & & & & & \\
\hline & Revenue from grain & 76450.00 & 65666.50 & 91541.50 & 87000.00 & 78083.25 \\
\hline & Revenue from straw & 9216.65 & 8308.32 & 9825.00 & 9900.00 & 9075.00 \\
\hline & Total revenue & 85966.70 & 73974.82 & 101366.50 & 96900.00 & 87158.25 \\
\hline & Gross Margin & 40496.90 & 28005.02 & 59296.70 & 52080.20 & 37688.45 \\
\hline & Rank of gross margin & III & V & I & II & IV \\
\hline
\end{tabular}

Table.12 Gross margin of wheat (Rs./ha) at AMTRC, Sarlahi during 2075/2076

\begin{tabular}{|c|c|c|c|c|c|c|}
\hline S.No. & Particulars & $\begin{array}{c}\mathbf{T}_{\mathbf{1}} \\
\text { (CSR) }\end{array}$ & $\mathbf{T}_{\mathbf{2}} \mathbf{( S R )}$ & $\begin{array}{c}\mathbf{T}_{\mathbf{3}} \\
\text { (PTOSD) }\end{array}$ & $\mathbf{T}_{\mathbf{4}}(\mathbf{R Z )}$ & $\begin{array}{c}\mathbf{T}_{\mathbf{5}} \\
\text { (Check) }\end{array}$ \\
\hline & Variable costs: & & & & & \\
\hline 01. & Land preparation cost & 6500.00 & 7000.00 & 4000.00 & 6750.00 & 10500.00 \\
\hline $\mathbf{0 2 .}$ & Seed cost & 9000.00 & 9000.00 & 9000.00 & 9000.00 & 9000.00 \\
\hline $\mathbf{0 3 .}$ & Fertilizer cost & 11819.80 & 11819.80 & 11819.80 & 11819.80 & 11819.80 \\
\hline $\mathbf{0 4 .}$ & Herbicide cost & 1350.00 & 1350.00 & 1350.00 & 1350.00 & 1350.00 \\
\hline $\mathbf{0 5 .}$ & Labor cost & 6300.00 & 6300.00 & 5400.00 & 5400.00 & 6300.00 \\
\hline $\mathbf{0 6 .}$ & Machine hire cost & 10500.00 & 10500.00 & 10500.00 & 10500.00 & 10500.00 \\
\hline & Total variable costs & 45469.80 & 45969.80 & 42069.80 & 44819.80 & 49469.80 \\
\hline & Revenue: & & & & & \\
\hline & Revenue from grain & 84513.24 & 94733.24 & 96133.34 & 96133.24 & 98466.48 \\
\hline & Revenue from straw & 13609.98 & 14000.01 & 14319.99 & 13695.99 & 14709.99 \\
\hline & Total revenue & 98123.22 & 108733.25 & 110453.23 & 109829.23 & 113176.47 \\
\hline & Gross Margin & 52053.42 & 62763.45 & 68383.43 & 65009.43 & 63706.67 \\
\hline & Rank of gross margin & V & IV & I & II & III \\
\hline
\end{tabular}


Table.13 Average of two years gross margin of wheat (Rs./ha) at AMTRC, Sarlahi during 2074/075-2075/2076

\begin{tabular}{|c|c|c|c|c|c|c|}
\hline $\begin{array}{c}\text { S. } \\
\text { No. }\end{array}$ & Particulars & $\begin{array}{c}\mathbf{T}_{\mathbf{1}} \\
\text { (CSR) }\end{array}$ & $\mathbf{T}_{\mathbf{2}}$ (SR) & $\begin{array}{c}\mathbf{T}_{\mathbf{3}} \\
\text { (PTOSD) }\end{array}$ & $\mathbf{T}_{\mathbf{4}}(\mathbf{R Z )}$ & $\begin{array}{c}\mathbf{T}_{\mathbf{5}} \\
\text { (Check) }\end{array}$ \\
\hline & Variable costs: & & & & & \\
\hline $\mathbf{0 1 .}$ & Land preparation cost & 6500.00 & 7000.00 & 4000.00 & 6750.00 & 10500.00 \\
\hline $\mathbf{0 2 .}$ & Seed cost & 9000.00 & 9000.00 & 9000.00 & 9000.00 & 9000.00 \\
\hline $\mathbf{0 3 .}$ & Fertilizer cost & 11819.80 & 11819.80 & 11819.80 & 11819.80 & 11819.80 \\
\hline $\mathbf{0 4 .}$ & Herbicide cost & 1350.00 & 1350.00 & 1350.00 & 1350.00 & 1350.00 \\
\hline $\mathbf{0 5 .}$ & Labor cost & 6300.00 & 6300.00 & 5400.00 & 5400.00 & 6300.00 \\
\hline $\mathbf{0 6 .}$ & Machine hire cost & 10500.00 & 10500.00 & 10500.00 & 10500.00 & 10500.00 \\
\hline & Total variable costs & 45469.80 & 45969.80 & 42069.80 & 44819.80 & 49469.80 \\
\hline & Revenue: & & & & & \\
\hline & Revenue from grain & 80631.62 & 80199.87 & 93837.37 & 91566.62 & 88274.87 \\
\hline & Revenue from straw & 11413.32 & 11154.17 & 12072.50 & 11798.00 & 11892.50 \\
\hline & Total revenue & $\mathbf{9 2 0 4 4 . 9 4}$ & $\mathbf{9 1 3 5 4 . 0 4}$ & $\mathbf{1 0 5 9 0 9 . 8 7}$ & $\mathbf{1 0 3 3 6 4 . 6 2}$ & $\mathbf{1 0 0 1 6 7 . 3 6}$ \\
\hline & Gross Margin & 46575.14 & 45384.24 & 63840.07 & 58544.82 & 50697.56 \\
\hline & Rank of gross margin & IV & V & I & II & III \\
\hline
\end{tabular}

Fig.1 Area and production of wheat in Nepal (2007/008-20167/2017

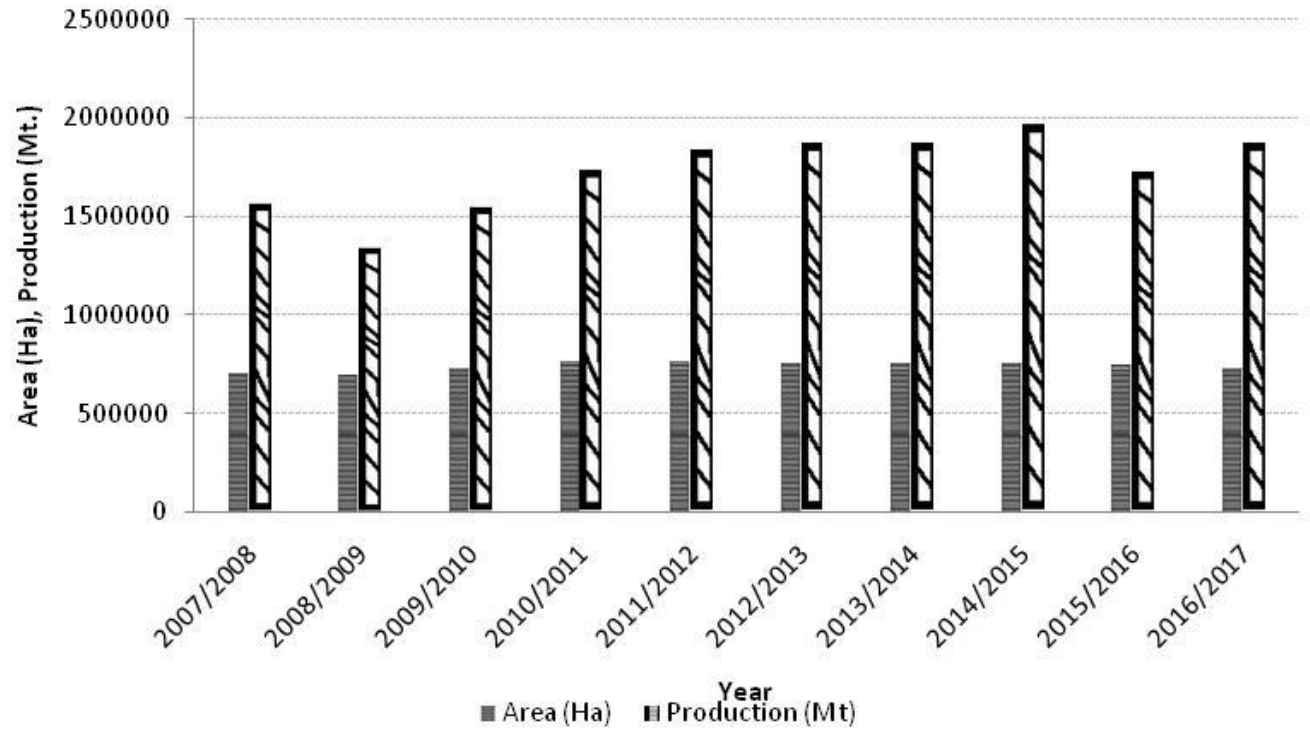


Fig.2 wheat yield $(\mathrm{Kg} / \mathrm{ha})$ in Nepal

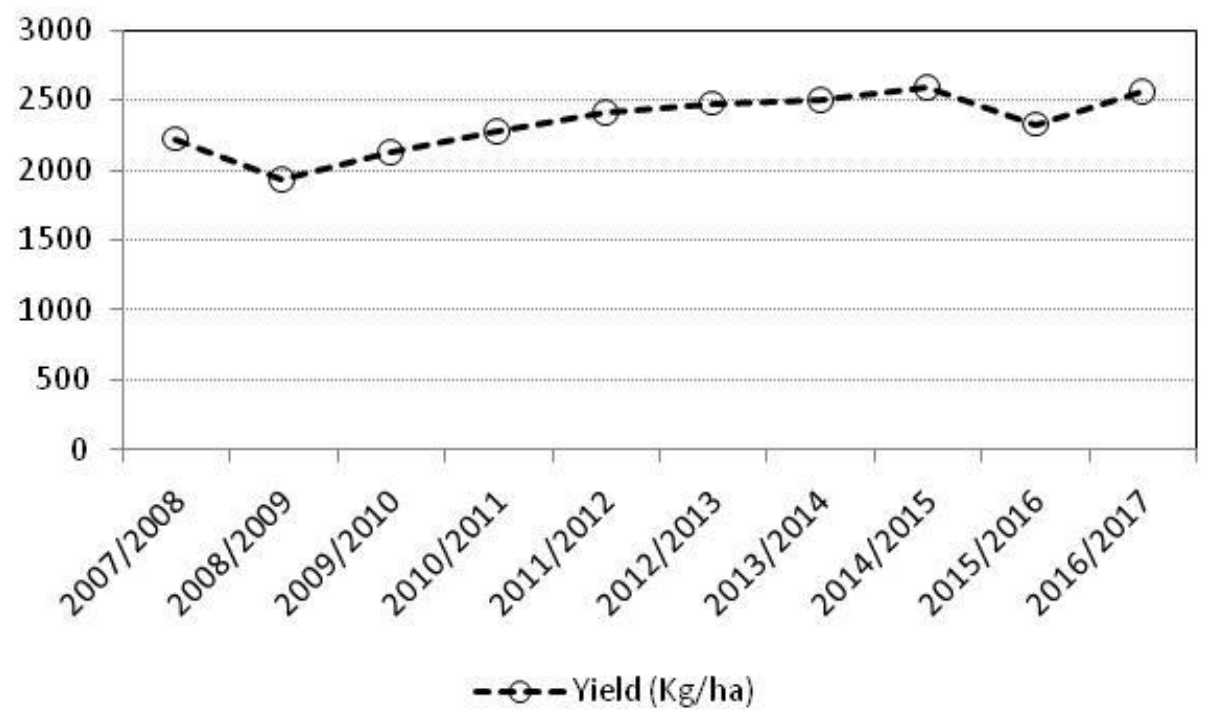

The lowest revenue was recorded in $\mathrm{T}_{2}$ (Rs. 73974.82/ha). Thus, the highest gross margin was obtained in $\mathrm{T}_{3}$ (Rs. 59296.70/ha) followed by $\mathrm{T}_{4}$ (Rs. $52080.20 / \mathrm{ha}$ ). The $\mathrm{T}_{2}$ treatment obtained lowest gross margin of Rs. 28005.02/ha (Table 11).

During the year 2075/076 of the experiment, the variable cost incurred in treatments was found highest in $\mathrm{T}_{5}$ (Check) which was Rs.49469.80 followed by $\mathrm{T}_{2}$ of Rs. 45969.80/ha. The lowest variable cost was counted in $\mathrm{T}_{3}$ which was found as Rs. 42069.80/ha (Table 12). Similarly, the revenue from grain and straw yield was recorded highest in $\mathrm{T}_{5}$ which was Rs.113176.47/ha followed by $\mathrm{T}_{3}$ which was Rs. 110453.23/ha. While calculating the gross margin, it was found highest in $T_{3}$ which recorded Rs. 68383.43/ha followed by the treatment $\mathrm{T}_{4}$ which obtained Rs. 65009.43/ha and the lowest gross margin was observed in $T_{1}$ which was Rs. 52053.42/ha (Table 12).

The variable cost when calculated as average of two years was found highest in $T_{5}$ which was Rs. 49469.80/ha and the lowest cost of Rs. 42069.80/ha was recorded in $\mathrm{T}_{3}$ (Table 13). Similarly, the total revenue of grain and straw yield was obtained highest by $\mathrm{T}_{3}$ (Rs. 105909.87/ha) followed by $\mathrm{T}_{4}$ which recorded Rs. 103364.62/ha. It was lowest in $\mathrm{T}_{2}$ (Rs. 91354.04/ha). The average gross margin of two years (2074/2075-2075/2076) was highest in $\mathrm{T}_{3}$ which was Rs. 63840.07/ha followed by $\mathrm{T}_{4}$ where the gross margin was recorded as Rs. 58544.82/ha. The treatment $\mathrm{T}_{2}$ recorded the lowest gross margin of Rs.45384.24/ha in the experiment (Table 13).

Wheat in Nepal terai is first winter crop. Mechanization in wheat cultivation is gaining popularity in mid-hills too. One of the major factors is lack of working human resources in agricultural peak season followed by the policies of government which is encouraging farmers to buy certain farm machineries by providing subsidies. Mechanization has also supported to reduce drudgeries of farm family and increasing production ultimately resulting in the increment of farm income. There are many type of agricultural machineries used in wheat cultivation and are also several cultural practices. The two years (2074/075 and 2075/076) results of experiment conducted at AMTRC, Sarlahi revealed that the use of power tiller operated seed drill (PTOSD) machine $\left(\mathrm{T}_{3}\right)$ in wheat cultivation minimizes the cultivation costs, yields more production, and finally increases gross margin of the farm. 
The total variable cost in use of PTOSD machine in $\mathrm{T}_{3}$, was 17.58 per cent less than farmers' practices. Similarly the gross margin was also 25.92 per cent more than farmer's practices (Check) obtained in PTOSD machine used treatment. The production was also highest in this treatment among other practices which was $3547.50 \mathrm{~kg} / \mathrm{ha}$, and this yield was more than 10 per cent higher than farmer's practices.

There are other farming practices too, the use of power tiller operated seed drill machine reduces the cost and has no any effect on grain yield, either it yields more. In this experiment, use of this machine and technique of cultivation resulted better than other treatments followed in the trial. Therefore, the use of power tiller operated seed drill machine can be economical for wheat cultivation particularly in terai area of Nepal if no other better machines are available.

\section{References}

Abdi Reza, H. R. Ghasemzadeh, S. Abdollahpour, M. Sabzeparvar, A. Dabbag and M. Nasab. 2010. Modeling and analysis of mechanization projects of wheat production by GERT networks. Agricultural Science in China. Vol. 9, Issue 7, July 2010, pp 10781083.

ASS, 2018. Statistical information on Nepalese agriculture. 2073/2074 (2016/2017). GoN/Ministry of Agriculture, Land Management and Cooperatives/Monitoring, Evaluation and Statistics Division/Agriculture Statistics Section, Singhdurbar, Kathmandu, Nepal.2018.

Aurangzeb, M., S. Nigar and M. Khan. 2007. Labor requirements model for the wheat crop under mechanized and traditional farming systems in the NWFP; A case study of Peshawar district. Sarhad J. Agric. Vol. 23. No. 1, 2007.

Basnyat, M. Agricultural mechanization in Nepal. ACIAR-IFPRI. Presented in ACIAR-IFPRI two days Regional Dialogue on Machine
Reforms for sustainable intensification of agriculture in south Asia on July 21-22, 2017 in New Delhi, India,

CIMMYT. Wheat Atlas Thttp://wheatatlas.org/country/environment/ NPL/22510

Devkota, Niranjan and Ram Kumar Phuyal. 2015. Climatic impact on wheat production in Terai of Nepal. The journal of development and administrative studies (JODAS), vol 23 (1-2), pp 1-22.

Din R. and N. R. Khattak. 2018. Impacts of farm mechanization on wheat and maize crops productivity in Peshawar valley. Sarhad journal of agriculture, 34(3):516-525.

Emami, M., M. Almassi, H. Bakhoda and I. Kalantari. 2018. Agricultural mechanization, a key to food security in developing countries: strategy formulating for Iran. Agriculture and food security 7, Article no.: 24 (2018).

FAO, 2018. FAO, 2018. Statistical database. Retrieved on 24 August 2018 from: http://www.fao.org/faostat/en/\#compare.

FAO, 2019. FAO in Nepal, Nepal at a glance. http://www.fao.org/nepal/fao-in-nepal/nepalat-a-glance/en/

Gauchan, D. and S. Shrestha. 2017. Agricultural and rural mechanization in Nepal: status, issues and options for future in Mandal S. M. A., S. D. Biggs, S. E. Justice, (Eds) 2017.Rural mechanization. A driver in agricultural change and rural development. Institute for inclusive finance and development (In.M), Dhaka, Bangladesh.

G. C., A.; J. H. Yeo and K. Ghimire. 2019. Determinants of farm mechanization in Nepal. Turkish Journal of Agriculture-Food Science and Technology, 7(1):87-91, 2019.

Hossain, A.H.M.S. and J. R. O'Callaghan.1996. A case study on the mechanization of wheat cultivation in Bangladesh. Journal of Agricultural Engineering Research, Vol. 65, Issue 3, November 1996, pp 175-181.

Joshi et al., 2012Oshi, K.D., Conroy, C., Witcombe, J.R., 2012. Agriculture, seed, and innovation in Nepal: industry and policy issues for the future. Project Paper, International Food Policy Research Institute, Washington, DC.

Kaur, A., 2017. Agricultural mechanization in Nepal. 
IFPRI. South Asia. April 7, 2017.

.Marahatta, S., R. Acharya and P. P. Joshi. 2018. Simulation of growth and yield of rice and wheat varieties under varied agronomic management and changing climatic scenario under subtropical condition of Nepal. Journal of Agriculture and Forestry University (2018), vol. 2:141-156.

Mcdonald, M., A. G. Park, M. Devkota, A. S. Davis. 2018. Increasing yield stability and input efficiencies with cost effective mechanization in Nepal. Article in Field Crops Research 228. September 2018. DOI:10.1016/j.fcr.2018.08.012.

MoF, 2019. Aarthik Sarvekshan, 2075/76 (Economic Survey, 2018/2019). Government of Nepal, Ministry of Finance, Singhdurbar, Kathmandu, Nepal.

NPC, 2017. Sustainable development goals. Government of Nepal, National Planning Commission (NPC), Kathmandu, Nepal.

Paudel, G., K. Koirala, D. K. C. and D. Rahut.2019. Small holder farmers' demand for farm mechanization in the mid-hills of Nepal. Conference paper. Conference: Southern Agricultural Economics Association (SAEA) Annual Meeting, at Birmingham, Alabama, February 2-5, 2019.

Pingali, P. L. (ed). 1999. CIMMYT 1998-99. World Wheat Facts and Trends. Global Wheat Research in a Changing World: Challenges and Achievements, Mexico, D. F., CIMMYT.

Pingali, P., and P.W. Heisey. 1996. Cereal crop productivity in developing countries: Past trends and future prospects. In Global Agricultural Science Policy for the TwentyFirst Century. Melbourne, Australia: Natural Resources and Environment. Pp. 51-94.

Pradhan, A., C. Mbohwa and H. P. W. Jayasuriya. 2016. Status and potentials of agricultural mechanization in Sunsari district, Nepal (2016).AGRIS: International information system for the agricultural science and technology.

Rahman, M. S., M. A. Monayem Miah, Moniruzzaman and S. Hossain. 2018. Impact of farm mechanization on labor use for wheat cultivation in northern Bangladesh. Journal of Animal and Plant Sciences 21(3):2011, pp589-594.
Rosegrant, M.W., M.A. Sombilla, R.V. Gerpacio, and C. Ringler. 1997. Global food markets and US exports in the twenty-first century. Paper presented at the Illinois World Food and Sustainable Agriculture Program Conference, Meeting the Demand for Food in the 21st Century: Challenges and Opportunities, 28 May, University of Illinois, Urbana-Champaign.

Sharma, K. 2017. Agriculture mechanization: Rental Market. The Himalayan Times. December 11, 2017.

Shrestha, $\mathrm{S}_{\mathrm{a}}$. 2012. Status of agricultural mechanization in Nepal. https://www.researchgate.net/publication/228 534387_Status_of_Agricultural_Mechanizati on_in_Nepal

Shrestha, $S_{b}$. 2012. Study on performance of conservation tillage equipment for wheat and maize planting in Nepal. https://www.researchgate.net/publication/228 534387_Status_of_Agricultural_Mechanizati on_in_Nepal

Takeshima, H. 2017a. Custom-hired tractor services and returns to scale in small holder agriculture; a production function approach. Agric. Econ. 48, 363-372..

Takeshima $2017_{\mathrm{b}}$. Overview of the evolution of agricultural mechanization in Nepal. IFPRI discussion paper 01662, Development Strategy and Governance Division. International Food Policy Research Institute, Washington, DC.

Timsina, K. P., Y. N. Ghimire, D. Gauchan, S. Suvedi and S. P. Adhikari. 2018. Lessons for promotion of new agricultural technology: a case of Vijaya wheat variety in Nepal. Agriculture and Food Security 2018 7:63.

Wang, X., Yamauchi, F. Otsuka, K. and Huang, J. 2016. Wage growth, landholding, and mechanization in Chinese agriculture. World Dev. 86, 30-45.

Wiggins, S. and Keats, S. 2014. Rural wages in Asia. Overseas Development Institute 203 Blackfriars Road London SEI 8NJ, United Kingdom.

Yamin, Muhammad, A. L. Tahir (Late), A. Nasir and M. Yaseen. 2011. Studying the impact of farm mechanization on wheat production in Punjab-Pakistan. Soil Environ. 30(2):151154, 2011. 


\section{How to cite this article:}

Ram Nath Jha, Md. Shamshad Ansari, Manish Thakur and Ram Abtar Mahato. 2019. Production Evaluation of Wheat through the Use of Different Cultivation Practices Using Different Machineries at Agricultural Machinery Testing and Research Centre (AMTRC), Sarlahi, Nepal. Int.J.Curr.Microbiol.App.Sci. 8(11): 1483-1503.

doi: https://doi.org/10.20546/ijcmas.2019.811.173

Annex.1 Detail cost of production and revenue (2074/2075)

\begin{tabular}{|c|c|c|c|c|c|}
\hline Particulars & $\begin{array}{c}\mathrm{T}_{1} \\
\mathrm{CSR}\end{array}$ & $\begin{array}{r}\mathbf{T}_{2} \\
\mathrm{SR}\end{array}$ & $\begin{array}{c}\mathrm{T}_{3} \\
\text { PTOSD }\end{array}$ & $\begin{array}{r}\mathbf{T}_{4} \\
\mathbf{R Z} \\
\end{array}$ & $\begin{array}{c}\mathbf{T}_{5} \\
\text { Check }\end{array}$ \\
\hline \multicolumn{6}{|l|}{ Revenue: } \\
\hline Grain yield at $14 \%$ m.c. $(\mathrm{Kg} / \mathrm{ha})$ & 3070.00 & 2626.66 & 3433.33 & 3480 & 3123.33 \\
\hline Straw yield $(\mathrm{kg} / \mathrm{ha})$ & 3686.66 & 3323.33 & 4773.33 & 3960 & 3630 \\
\hline Return from Grain (Rs/ha) & 76750 & 65666.5 & 96133.24 & 87000 & 78083.25 \\
\hline Return from straw (Rs/ha) & 9216.65 & 8308.33 & 14319.99 & 9900 & 9075 \\
\hline Total Revenue: & 85966.7 & 73974.8 & 110453.23 & 96900 & 87158.25 \\
\hline Dry land preparation cost (Rs/ha) (Cultivator) & 3000.00 & 0.00 & 0.00 & 3000.00 & 9000.00 \\
\hline Rotavator / planking cost (Rs/ha) & 3500.00 & 7000.00 & 0.00 & 0.00 & 1500.00 \\
\hline Sowing machine hire $\operatorname{cost}(\mathrm{Rs} / \mathrm{ha})$ & 0.00 & 0.00 & 4000.00 & 3750.00 & 0.00 \\
\hline Land preparation cost & 6500.00 & 7000.00 & 4000.00 & 6750.00 & 10500.00 \\
\hline Seed Cost (Rs75/kg) & 9000.00 & 9000.00 & 9000.00 & 9000.00 & 9000.00 \\
\hline DAP (108.7 kg/ha) & 5652.40 & 5652.40 & 5652.40 & 5652.40 & 5652.40 \\
\hline Urea $(174.9 \mathrm{~kg} / \mathrm{ha})$ & 4547.40 & 4547.40 & 4547.40 & 4547.40 & 4547.40 \\
\hline MoP (45 kg/ha) & 1620.00 & 1620.00 & 1620.00 & 1620.00 & 1620.00 \\
\hline Total Fertilizers Cost (Rs/ha) & 11819.8 & 11819.8 & 11819.8 & 11819.8 & 11819.80 \\
\hline \multicolumn{6}{|l|}{ Herbicide cost $(\mathrm{Rs} / \mathrm{kg})$} \\
\hline 2-4-D (2.25 lit/ha) (Rs/ha) & 1350.00 & 1350.00 & 1350.00 & 1350.00 & 1350.00 \\
\hline Labor for sowing cost & 1350.00 & 1350.00 & 450.00 & 450 & 1350 \\
\hline Labor cost for weeding (Rs/ha) & 0 & 0 & 0.00 & 0 & 0 \\
\hline Labor cost for fertilizer application (Rs/ha) & 900 & 900 & 900.00 & 900 & 900 \\
\hline Labor for irrigation Cost (Rs/ha) & 1800 & 1800 & 1800.00 & 1800 & 1800 \\
\hline Labor for harvesting Cost (Rs/ha) & 900 & 900 & 900.00 & 900 & 900 \\
\hline $\begin{array}{l}\text { Labor for threshing and cleaning Cost (10\% of GYLD) } \\
\text { (Rs/ha) }\end{array}$ & 1350 & 1350 & 1350.00 & 1350 & 1350 \\
\hline Total labor cost & 6300 & 6300 & 5400 & 5400 & 6300 \\
\hline Machine cost for harvesting & 6000 & 6000 & 6000 & 6000 & 6000 \\
\hline Thresher hire cost & 4500 & 4500 & 4500 & 4500 & 4500 \\
\hline Total machine hire cost & 10500 & 10500 & 10500 & 10500 & 10500 \\
\hline Total variable cost & 45469.8 & 45969.8 & 42069.8 & 44819.8 & 49469.8 \\
\hline Gross margin (Revenue-Variable cost) & 40496.9 & 28005 & 68383.43 & 52080.2 & 37688.45 \\
\hline
\end{tabular}

\begin{tabular}{|c|c|c|c|c|}
\hline \multicolumn{2}{|c|}{ Price rate } & \\
\hline S. no. & Item & & Rate \\
\hline 1 & Farm gate price of wheat grain $(\mathrm{Rs} / \mathrm{kg})$ & & & 25 \\
\hline 2 & Farm gate price of straw $(\mathrm{Rs} / \mathrm{kg})$ & & & 2.5 \\
\hline 3 & Labor Rate/day & & & 450 \\
\hline 4 & Seed price $(\mathrm{Rs} / \mathrm{Kg})$ & & 75 \\
\hline 5 & DAP price $(\mathrm{Rs} / \mathrm{Kg})$ & & 52 \\
\hline 6 & Urea price $(\mathrm{Rs} / \mathrm{Kg})$ & & 26 \\
\hline 7 & Potash price $(\mathrm{Rs} / \mathrm{Kg})$ & & & 36 \\
\hline 8 & Herbicides price $(\mathrm{Rs} / \mathrm{Lt})$ & & 600 \\
\hline
\end{tabular}


Annex.2 Detail cost of production and revenue (2075/2076)

\begin{tabular}{|c|c|c|c|c|c|}
\hline Particulars & $\begin{array}{c}T_{1} \\
\text { CSR }\end{array}$ & $\begin{array}{l}\mathbf{T}_{2} \\
\mathrm{SR}\end{array}$ & $\begin{array}{c}\mathbf{T}_{3} \\
\text { PTOSD }\end{array}$ & $\begin{array}{r}\mathbf{T}_{4} \\
\mathbf{R Z}\end{array}$ & $\begin{array}{c}\mathrm{T}_{5} \\
\text { Check }\end{array}$ \\
\hline \multicolumn{6}{|l|}{ Revenue: } \\
\hline Grain yield at $14 \%$ m.c. $(\mathrm{Kg} / \mathrm{ha})$ & 3018.33 & 3383.33 & 3433.33 & 3433.33 & 3516.66 \\
\hline Straw yield (kg/ha) & 4536.66 & 4666.67 & 4773.33 & 4565.33 & 4903.33 \\
\hline Return from Grain (Rs/ha) & 84513.24 & 94733.24 & 96124.33 & 96133.24 & 98466.5 \\
\hline Return from straw (Rs/ha) & 13609.98 & 14000.01 & 14319.99 & 13695.99 & 14710 \\
\hline Total revenue & 98123.22 & 108733.25 & 110453.23 & 109829.23 & 113176 \\
\hline Dry land preparation cost (Rs/ha) (Cultivator) & 3000 & 0 & 0.00 & 3000 & 9000 \\
\hline Rotavator / planking cost (Rs/ha) & 3500 & 7000 & 0.00 & 0 & 1500 \\
\hline Sowing machine hire $\operatorname{cost}(\mathrm{Rs} / \mathrm{ha})$ & 0 & 0 & 4000.00 & 3750 & 0 \\
\hline Land preparation cost (Rs/ha) & 6500 & 7000 & 4000.00 & 6750 & 10500 \\
\hline Seed Cost (Rs75/kg) & 9000 & 9000 & 9000.00 & 9000 & 9000 \\
\hline \multicolumn{6}{|c|}{ Fertilizers Cost (Rs/ha) } \\
\hline DAP (108.7 kg/ha) & 5652.4 & 5652.4 & 5652.40 & 5652.4 & 5652.4 \\
\hline Urea $(174.9 \mathrm{~kg} / \mathrm{ha})$ & 4547.4 & 4547.4 & 4547.40 & 4547.4 & 4547.4 \\
\hline MoP (45 kg/ha) & 1620 & 1620 & 1620.00 & 1620 & 1620 \\
\hline Total fertilizer cost (Rs/ha) & 11819.8 & 11819.8 & 11819.80 & 11819.8 & 11819.8 \\
\hline \multicolumn{6}{|c|}{ Herbicide cost (Rs/kg) } \\
\hline 2-4-D (2.25 lit/ha) (Rs/ha) & 1350 & 1350 & 1350.00 & 1350 & 1350 \\
\hline Labor for sowing cost & 1350 & 1350 & 450.00 & 450 & 1350 \\
\hline Labor cost for weeding (Rs/ha) & 0 & 0 & 0.00 & 0 & 0 \\
\hline Labor cost for fertilizer application (Rs/ha) & 900 & 900 & 900.00 & 900 & 900 \\
\hline Labor for irrigation Cost (Rs/ha) & 1800 & 1800 & 1800.00 & 1800 & 1800 \\
\hline Labor for harvesting Cost (Rs/ha) & 900 & 900 & 900.00 & 900 & 900 \\
\hline $\begin{array}{l}\text { Labor for threshing and cleaning Cost (10\% of GYLD) } \\
\qquad \text { (Rs/ha) }\end{array}$ & 1350 & 1350 & 1350.00 & 1350 & 1350 \\
\hline Total labor cost (Rs/ha) & 6300 & 6300 & 5400.00 & 5400 & 6300 \\
\hline Machine cost for harvesting & 6000 & 6000 & 6000.00 & 6000 & 6000 \\
\hline Thresher hire cost & 4500 & 4500 & 4500.00 & 4500 & 4500 \\
\hline Total machine hire cost (Rs/ha) & 10500 & 10500 & 10500.00 & 10500 & 10500 \\
\hline Total variable cost (Rs/ha) & 45469.8 & 45969.8 & 42069.80 & 44819.8 & 49469.8 \\
\hline Gross margin (Rs/ha) & 52653.42 & 62763.45 & 68383.43 & 65009.43 & 63706.7 \\
\hline
\end{tabular}

\begin{tabular}{|c|c|}
\hline Price rate: & Rate \\
\hline Item & 28.00 \\
\hline Farm gate price of wheat grain $(\mathrm{Rs} / \mathrm{kg})$ & 3.00 \\
\hline Farm gate price of straw $(\mathrm{Rs} / \mathrm{kg})$ & 450.00 \\
\hline Labor Rate/day & 75.00 \\
\hline Seed price $(\mathrm{Rs} / \mathrm{Kg})$ & 52.00 \\
\hline DAP price $(\mathrm{Rs} / \mathrm{Kg})$ & 26.00 \\
\hline Urea price $(\mathrm{Rs} / \mathrm{Kg})$ & 36.00 \\
\hline Potash price $(\mathrm{Rs} / \mathrm{Kg})$ & 600.00 \\
\hline
\end{tabular}


Annex.3 Detail two years average cost of production and revenue (2074/2075-2075/2076)

\begin{tabular}{|c|c|c|c|c|c|}
\hline Particulars & $\begin{array}{c}\mathrm{T}_{1} \\
\mathrm{CSR}\end{array}$ & $\begin{array}{r}\mathbf{T}_{2} \\
\text { SR }\end{array}$ & $\begin{array}{c}\text { T }_{3} \\
\text { PTOSD }\end{array}$ & $\begin{array}{r}\mathbf{T}_{4} \\
\mathbf{R Z}\end{array}$ & $\begin{array}{c}\mathbf{T}_{5} \\
\text { Check }\end{array}$ \\
\hline \multicolumn{6}{|l|}{ Revenue: } \\
\hline Grain yield at $14 \%$ m.c. (Kg/ha) & 3044.17 & 3005.00 & 3547.50 & 3456.67 & 3320.00 \\
\hline Straw yield (kg/ha) & 4111.66 & 3995.00 & 4351.67 & 4262.67 & 4266.67 \\
\hline Return from Grain (Rs/ha) & 80631.62 & 80199.87 & 93837.37 & 91566.62 & 88274.87 \\
\hline Return from straw (Rs/ha) & 11413.32 & 11154.17 & 12072.50 & 11798.00 & 11892.50 \\
\hline Total revenue & 92044.94 & 91354.04 & 105909.87 & 103364.62 & 100167.36 \\
\hline $\begin{array}{c}\text { Dry land preparation cost (Rs/ha) } \\
\text { (Cultivator) }\end{array}$ & 3000.00 & 0.00 & 0.00 & 3000.00 & 9000.00 \\
\hline Rotavator / planking cost (Rs/ha) & 3500.00 & 7000.00 & 0.00 & 0.00 & 1500.00 \\
\hline Sowing machine hire $\operatorname{cost}(\mathbf{R s} / \mathrm{ha})$ & 0.00 & 0.00 & 4000.00 & 3750.00 & 0.00 \\
\hline Land preparation cost & 6500.00 & 7000.00 & 4000.00 & 6750.00 & 10500.00 \\
\hline Seed Cost (Rs75/kg) & 9000.00 & 9000.00 & 9000.00 & 9000.00 & 9000.00 \\
\hline \multicolumn{6}{|l|}{ Fertilizers Cost (Rs/ha) } \\
\hline DAP $(108.7$ kg/ha) & 5652.40 & 5652.40 & 5652.40 & 5652.40 & 5652.40 \\
\hline Urea (174.9kg/ha) & 4547.40 & 4547.40 & 4547.40 & 4547.40 & 4547.40 \\
\hline MoP (45 kg/ha) & 1620.00 & 1620.00 & 1620.00 & 1620.00 & 1620.00 \\
\hline Total fertilizer cost & 11819.80 & 11819.80 & 11819.80 & 11819.80 & 11819.80 \\
\hline \multicolumn{6}{|l|}{ Herbicide cost (Rs/kg) } \\
\hline 2-4-D (2.25 lit/ha) (Rs/ha) & 1350.00 & 1350.00 & 1350.00 & 1350.00 & 1350.00 \\
\hline Labor for sowing/ transplanting cost & 1350.00 & 1350.00 & 450.00 & 450.00 & 1350.00 \\
\hline Labor cost for weeding (Rs/ha) & 0.00 & 0.00 & 0.00 & 0.00 & 0.00 \\
\hline $\begin{array}{l}\text { Labor cost for fertilizer application } \\
\text { (Rs/ha) }\end{array}$ & 900.00 & 900.00 & 900.00 & 900.00 & 900.00 \\
\hline Labor for irrigation Cost (Rs/ha) & 1800.00 & 1800.00 & 1800.00 & 1800.00 & 1800.00 \\
\hline Labor for harvesting Cost (Rs/ha) & 900.00 & 900.00 & 900.00 & 900.00 & 900.00 \\
\hline $\begin{array}{l}\text { Labor for threshing and cleaning Cost } \\
\text { (10\% of GYLD) (Rs/ha) }\end{array}$ & 1350.00 & 1350.00 & 1350.00 & 1350.00 & 1350.00 \\
\hline Labor cost & 6300.00 & 6300.00 & 5400.00 & 5400.00 & 6300.00 \\
\hline Machine cost for harvesting & 6000.00 & 6000.00 & 6000.00 & 6000.00 & 6000.00 \\
\hline Thresher hire cost & 4500.00 & 4500.00 & 4500.00 & 4500.00 & 4500.00 \\
\hline Total machine hire cost & 10500.00 & 10500.00 & 10500.00 & 10500.00 & 10500.00 \\
\hline Total Variable Cost (Rs/ha) & 45469.80 & 45969.80 & 42069.80 & 44819.80 & 49469.80 \\
\hline Gross margin (Rs/ha) & 46575.14 & 45384.24 & 63840.07 & $\mathbf{5 8 5 4 4 . 8 2}$ & 50697.56 \\
\hline
\end{tabular}

